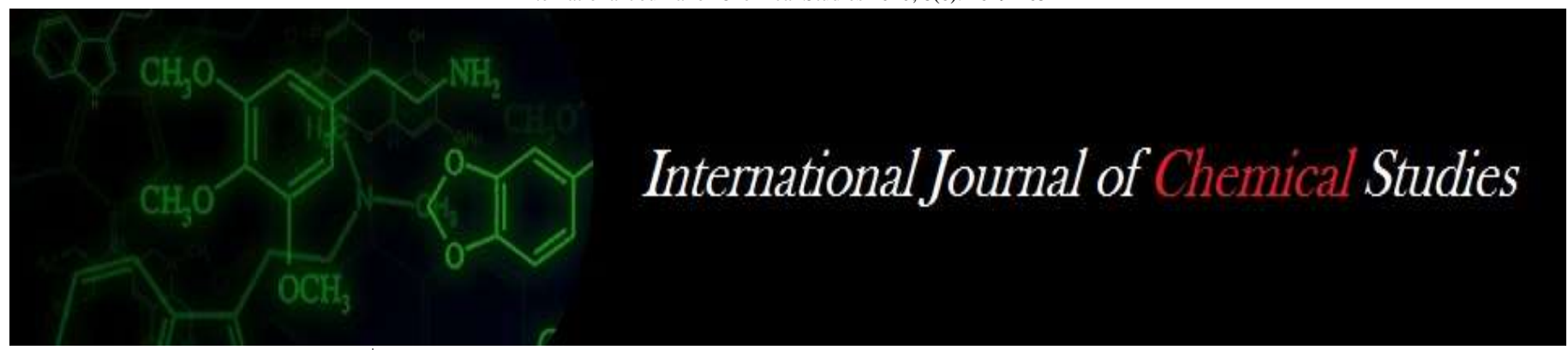

P-ISSN: 2349-8528

E-ISSN: 2321-4902

www.chemijournal.com

IJCS 2020; 8(6): 2649-2652

(C) 2021 IJCS

Received: 11-08-2020

Accepted: 20-09-2020

\section{AV Gharatkar}

Department of Animal

Husbandry and Dairy Science,

Dr. Balasaheb Sawant Konkan

Krishi Vidyapeeth, Dapoli,

Maharashtra, India

\section{MA Waikar}

Department of Animal

Husbandry and Dairy Science,

Dr. Balasaheb Sawant Konkan

Krishi Vidyapeeth, Dapoli,

Maharashtra, India

\section{SS Ramod}

Department of Animal

Husbandry and Dairy Science,

Dr. Balasaheb Sawant Konkan

Krishi Vidyapeeth, Dapoli,

Maharashtra, India

NN Prasade

Department of Animal

Husbandry and Dairy Science,

Dr. Balasaheb Sawant Konkan

Krishi Vidyapeeth, Dapoli,

Maharashtra, India

\section{VS Dandekar}

Department of Animal

Husbandry and Dairy Science,

Dr. Balasaheb Sawant Konkan

Krishi Vidyapeeth, Dapoli,

Maharashtra, India
Corresponding Author: AV Gharatkar

Department of Animal

Husbandry and Dairy Science,

Dr. Balasaheb Sawant Konkan

Krishi Vidyapeeth, Dapoli,

Maharashtra, India

\section{Study on physio-chemical and sensory properties of chhana burfi incorporate with chocolate flavoured whey protein powder}

\author{
AV Gharatkar, MA Waikar, SS Ramod, NN Prasade and VS Dandekar
}

DOI: https://doi.org/10.22271/chemi.2020.v8.i6al.11182

\begin{abstract}
Chhana burfi blended with chocolate flavored whey protein powder is a unique innovative product with rich chocolaty taste and flavour and has soft body texture. In present investigation, Chhana burfi was manufactured from buffalo milk chhana. The burfi was incorporated with chocolate flavoured whey protein powder. Sugar was added at the rate of 24 per cent of original wight of chhana for all three treatments. Whey protein powder was used at different levels viz., 5 per cent $\left(\mathrm{T}_{1}\right), 10$ per cent $\left(\mathrm{T}_{2}\right)$ and 15 percent $\left(\mathrm{T}_{3}\right)$ of the plain chhana $(\mathrm{w} / \mathrm{w})$. Among these levels, Chhana burfi prepared with 10 per cent level of addition of chocolate flavoured whey protein powder found to be acceptable by sensory panel ( 9 point hedonic scale). The prepared chhana burfi was subjected to physico-chemical and microbial analysis. Addition of whey protein powder in chhana burfi improved sensory quality and acceptability of the product. It is concluded that chhana burfi incorporated with 10 per cent whey protein powder is best in overall acceptability and microbial quality.
\end{abstract}

Keywords: Chhana, burfi, whey protein, chocolate

\section{Introduction}

Heat and acid coagulated dairy products are prepared by coagulation of milk with organic/ inorganic acid at higher temperature followed by cooling and straining of coagulum (Sahu \& Das 2010). Chhana is an indigenous milk product obtained by heat and acid coagulation of milk followed by drainage of major quantity of whey. As chhana has a fairly high fat and protein content, and also contains some minerals, especially calcium and phosphorus, its food and nutritive value is fairly high. It is also a good source of fat-soluble vitamins A and D. With its high protein and low sugar content, chhana is highly recommended for diabetic patients.

Whey protein is a mixture of beta-lactoglobulin, alpha-lactalbumin, bovine serum albumin and immunoglobins. Whey proteins are rich with EAAs (Essential Amino Acids) including three BCAAs (Branched Chain Amino Acids) and also contain subcomponents of micro fractions which provide the benefits of elemental nitrogen and amino acids. Whey protein is considered a complete protein as it contains all nine essential amino acids. It is low in lactose content.

Burfi, is a khoa based, popular confection from the Indian sub-continent. It is a type of mithai. Different types of burfi vary greatly in their colour and texture. It is highly popular mainly because of their delicious taste and high nutritive value.

\section{Material and Methods}

For preparation of chhana burfi incorporated with chocolate flavoured whey protein powder, buffalo milk was received from Dairy farm, College of Agriculture, Dapoli, whereas chocolate flavoured whey protein powder was of Muscle Blaze company and sugar were purchased from the local market. The base of burfi, chhana was prepared as per the procedure given by Kadam et. al. (2017) and the chhana burfi was prepared as per the procedure standardized by Aneja et. al. (2002) with slight modifications.

The fresh good quality buffalo milk was filtered and heated at $80^{\circ} \mathrm{C}$ to $82^{\circ} \mathrm{C}$ for 10 minutes. The milk was cooled to $70^{\circ} \mathrm{C}$ and coagulanted with citric acid ( $2 \%$ solution). After coagulation, chhana was separated and the clear whey was drained by muslin cloth. Sugar was added @ 24 per cent of obtained weight of chhana. 
Chocolate flavoured whey protein powder was added as per treatment i.e., @ 5,10 and 15 per cent of chhana. The mixture were properly kneaded and heated on low flame for 2-3 minutes. Spreading of mixture on greasy tray for cooling I setting (1-2 hrs). After that, cut it into pieces and stored at refrigerated temperature.

\section{Flow diagram for preparation of chhana}

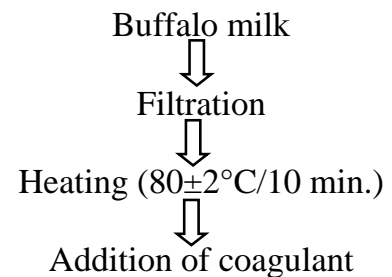

$\left(2 \%\right.$ citric acid solution at $\left.70^{\circ} \mathrm{C}\right)$

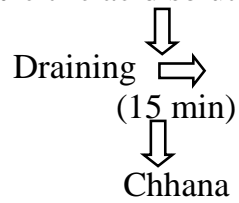

Fig 1: Flow diagram for preparation of chhana

\section{Flow diagram for preparation of chhana burfi}

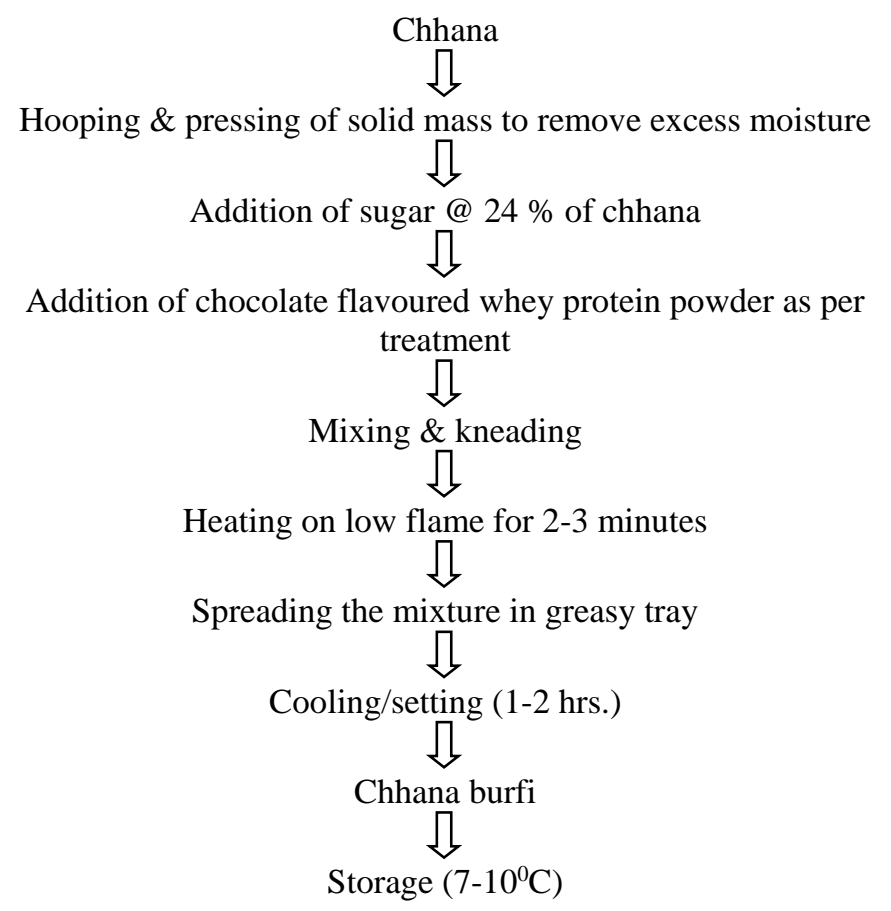

Fig 2: Flow diagram for preparation of chhana burfi

The total solids and protein content of milk and chhana burfi were determined as per IS: 1479 (part II), $1961^{[6]}$. The fat content of milk and chhana burfi was determined by using

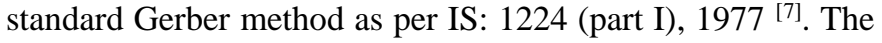
acidity of milk and chhana burfi was estimated according to IS: 1479 (part I), $1960^{[5]}$. The ash content of milk and chhana burfi was determined as per the procedure given in A.O.A.C. (1975) ${ }^{[1]}$. The lactose content of milk and chhana burfi was estimated as per IS: 1479 (II) 1961. The data were statistically analyzed according to Snedecor and Cochran (1994) ${ }^{[12]}$ using randomized block design.

\section{Results and Discussion}

The chemical analysis of the buffalo milk used for preparation of chhana burfi indicated on an average 15.54 per cent total solids, 6.32 per cent fat, 3.81 per cent protein, total sugar 4.81 per cent, 0.16 per cent acidity and 0.82 per cent ash. All these values lie within the range of legal standards for buffalo milk as described by PFA rules, 1976 cited by De (2011). The results are furnished in Table 2.

\section{Chemical analysis of chhana burfi Total solid content}

The total solids content of chhana burfi showed gradual increase with the increase in level of whey protein powder with values of $60.15\left(\mathrm{~T}_{1}\right), 61.55\left(\mathrm{~T}_{2}\right)$ and $62.83\left(\mathrm{~T}_{3}\right)$ per cent at 5,10 and 15 per cent level of whey protein powder. This gradual increase of total solid content from $T_{1}$ to $T_{3}$ may be due to higher amount of total solids content in whey protein powder $(98 \%)$. The highest total solids content was noticed at $\mathrm{T}_{3}(62.835 \%)$ i.e. Chhana burfi manufactured with 15 per cent whey protein powder, while lowest was observed at $\mathrm{T}_{1}$ $(60.15 \%)$ i.e. Chhana burfi manufactured with 5 per cent whey protein powder.

\section{Fat content}

The average fat content of Chhana burfi at 5,10 and 15 per cent level of whey protein powder was 22.94, 22.22 and 21.55 per cent respectively. It was noticed that highest fat content was observed at $\mathrm{T}_{1}$ (22.94) i.e. Chhana burfi prepared with 5 per cent whey protein powder and lowest at $\mathrm{T}_{3}(21.55)$ i.e. 15 per cent whey protein powder. Due to low fat content of whey protein powder i.e. 3.5 per cent, its incorporation reduced fat of the final product. Despite of that the difference between highest and lowest average fat content values of Chhana burfi as influenced by whey protein powder was only 1.39 .

\section{Protein content}

The perusal of data revealed that incorporation of whey protein powder had significantly affected the protein content of Chhana burfi. The significance of protein in dairy products is highly regarded due to its distinguishable role for adding nutritional quality to the product. It was observed that that incorporation of whey protein powder increased the protein content of Chhana burfi. The protein content of Chhana burfi increased with incorporation of whey protein powder from treatment $T_{1}$ to $T_{3}$. Due to higher protein per cent in whey protein powder i.e. 70 per cent, it increased the protein trend in the Chhana burfi incorporated with whey protein powder. The average protein per cent of Chhana burfi was 13.98, 16.28 and 18.41 per cent at 5,10 and 15 per cent of whey protein powder respectively. The highest protein value of Chhana burfi was reported for treatment $\mathrm{T}_{3}$ i.e. 18.41 per cent (@ $15 \% \mathrm{WPP}$ ) and that of lowest value was reported for treatment $\mathrm{T}_{1}$ i.e. 13.98 per cent (@ $5 \%$ WPP).

\section{Total sugar}

The total sugar content of chhana burfi was found to be 21.12, 20.75 and 20.41 per cent for treatment $T_{1}, T_{2}$ and $T_{3}$ respectively. The total sugar content in Chhana burfi results in gradual decrease from 21.12 to 20.41 per cent with increasing level of whey protein powder. The decreasing sugar content level of Chhana burfi may be due to low amount of sugar content in whey protein powder i.e. 11.2 per cent. The sugar (lactose) content of chhana was merely 1.9 per cent. During manufacturing of burfi cane sugar was added @ 24 per cent. This resulted in increasing total sugar percentage of mass of chhana and sugar, however WPP which contains negligible sugar resulted in reducing sugar percentage. 


\section{Ash content}

The perusal of data revealed that the ash content showed gradual decrease with increase in the level of whey protein powder. The average ash content of chhana burfi at 5, 10 and 15 per cent level of whey protein powder was $1.853,1.829$ and 1.807 per cent, respectively. The decreasing trend of ash in Chhana burfi may be due to the fact that whey protein powder contained lower percentage of ash i.e. 1.2 per cent.

\section{Acidity}

The results indicated that average acidity of burfi at 5,10 and 15 per cent level of whey protein powder was $0.371,0.383$, and 0.393 per cent, respectively. The acidity showed increasing trend with an increase in the level of whey protein powder.

\section{Sensory analysis of chhana burfi}

Sensory evaluation of any consumable product is the best method of judging the acceptability of the product by the consumers. Sensory evaluation plays vital role in product development as well as in determining the shelf-life of a product. The sensory assessment was done by studying the parameters like colour and appearance, body and texture, flavour and overall acceptability of the product by the panel of judges by using "Nine Point Hedonic Scale" score card. The results of the study presented herein under.

\section{Colour and appearance}

Colour and appearance is an important sensory attribute in the organoleptic assessment. Acceptance of any milk product by customers chiefly depends upon colour and appearance of the product.

The colour and appearance of Chhana burfi was significantly improved by addition of chocolate flavoured whey protein powder. There was increase in dark colour of Chhana burfi due to chocolaty colour of whey protein powder. As whey protein powder increases, the burfi resemble brown to chocolaty brown in colour. The average score for colour and appearance was recorded at 5,10 and 15 per cent level was 7.24, 7.99 and 8.05 respectively. The highest score (8.05) was obtained by the treatment $T_{3}$ and that of lowest score (7.24) was obtained by treatment $\mathrm{T}_{1}$.

\section{Flavour}

Whey protein used in the burfi is of chocolate flavoured. Consequently, the resultant product obtained chocolate flavour. The average score for flavour was recorded at 5, 10 and 15 per cent level was $7.38,8.34$ and 7.96 respectively. The highest score (8.34) was obtained by the treatment $\mathrm{T}_{2}$ i.e. chhana burfi prepared with 10 per cent whey protein powder and that of lowest score (7.38) was obtained by treatment $T_{1}$ i.e. chhana burfi prepared with 5 per cent whey protein powder.

\section{Body and texture}

The score for body and texture was recorded are 7.52, 8.43 and 8.07 at 5, 10 and 15 per cent level respectively. The highest score (8.43) was obtained by the treatment $\mathrm{T}_{2}$ i.e. chhana burfi prepared with 10 per cent whey protein powder and that of lowest score (7.52) was obtained by treatment $T_{1}$ i.e. chhana burfi prepared with 5 per cent whey protein powder.

\section{Overall acceptability}

The score for overall acceptability of chhana burfi was recorded $7.53,8.62$ and 8.13 at 5,10 and 15 per cent level respectively. The highest score (8.62) was obtained by the treatment $T_{2}$ i.e. chhana burfi prepared with 10 per cent whey protein powder and that of lowest score (7.53) was obtained by treatment $\mathrm{T}_{1}$ i.e. chhana burfi prepared with 5 per cent whey protein powder.

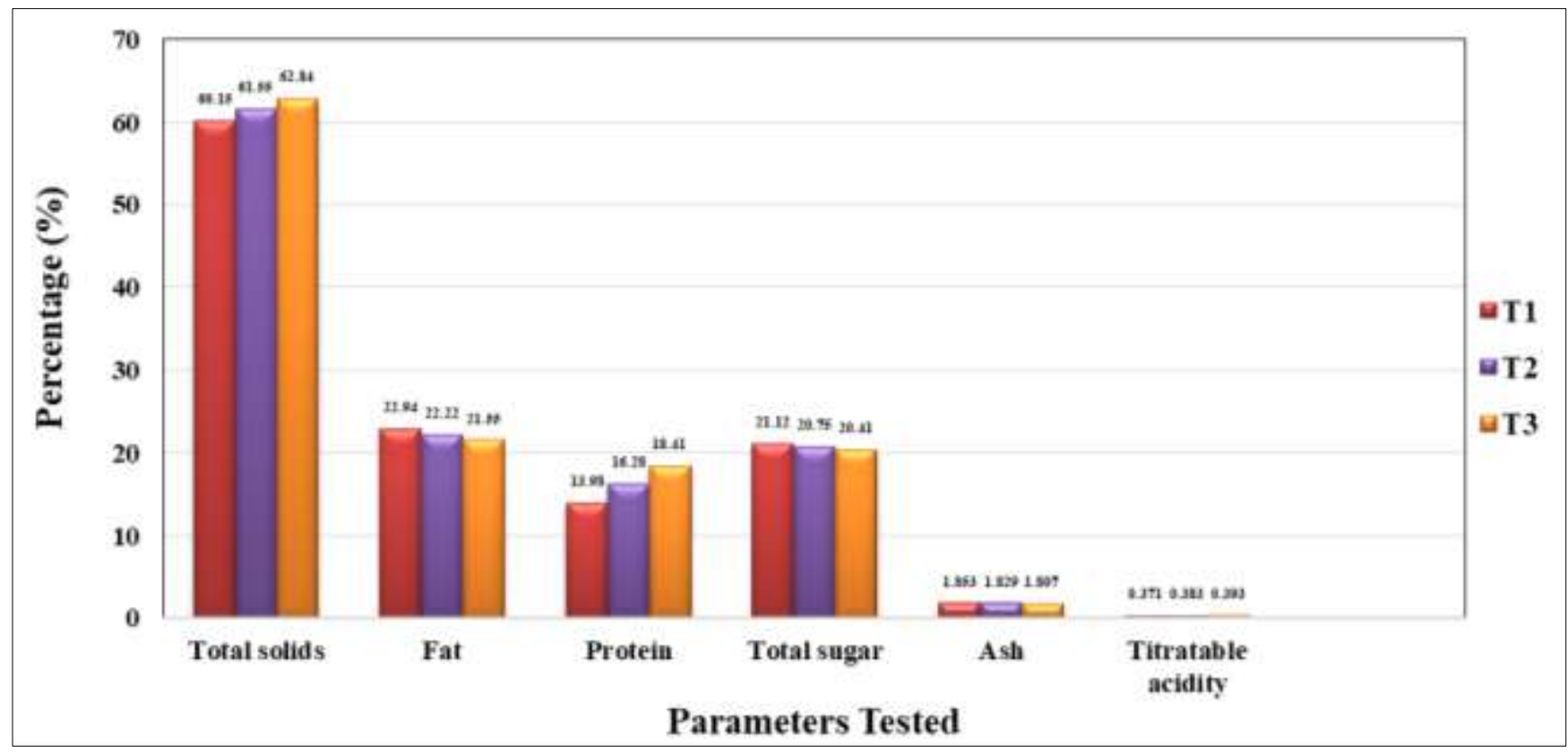

Fig 3: Physico-chemical analysis of chhana burfi 


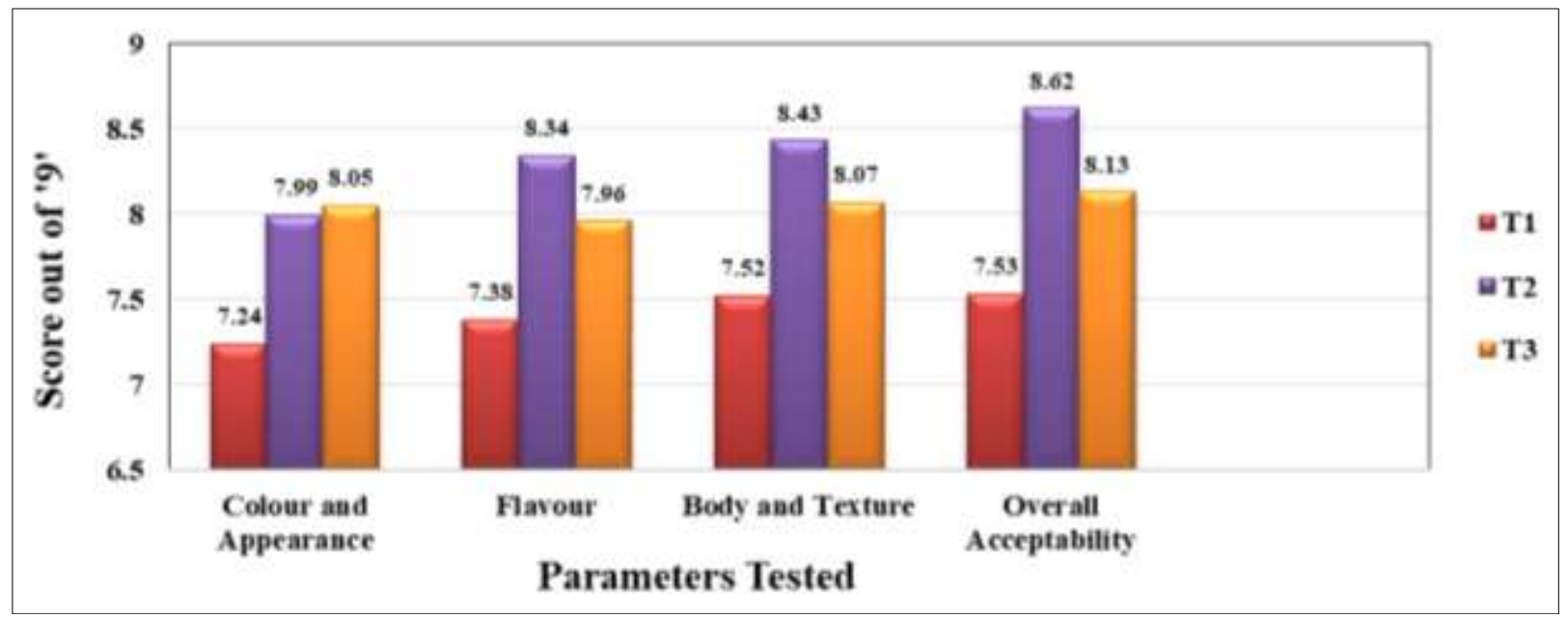

Fig 4: Sensory Analysis of chhana burfi

\section{Conclusion}

From the results, it could be concluded that chocolate flavoured whey protein powder could be successfully utilized for the manufacture of Chhana burfi. Addition of chocolate flavored whey protein powder improves the acceptability of product. Being enriched with whey protein powder, it can increase nutritional quality of burfi. The chhana burfi prepared from treatment $\mathrm{T}_{2}$ i.e. 10 per cent level of whey protein powder was most acceptable than rest of the treatments.
Table 1: Average chemical quality of buffalo milk (\%)

\begin{tabular}{|c|c|c|}
\hline Sr. No. & Constituents & $\mathbf{( \% )}$ \\
\hline 1. & Total Solids & 15.54 \\
\hline 2. & Fat & 6.321 \\
\hline 3. & Protein & 3.815 \\
\hline 4. & Total sugar & 4.81 \\
\hline 5. & Ash & 0.82 \\
\hline 6. & Titratable Acidity & 0.16 \\
\hline
\end{tabular}

Table 2: Average chemical quality of chhana burfi (\%)

\begin{tabular}{|c|c|c|c|c|c|c|}
\hline \multirow{2}{*}{ Levels of whey protein powder (\%) } & \multicolumn{6}{|c|}{ Constituents } \\
\cline { 2 - 7 } & Total solids & Fat & Protein & Total sugars & Ash & Acidity \\
\hline 5 & 60.15 & 22.94 & 13.98 & 21.12 & 1.853 & 0.371 \\
\hline 10 & 61.55 & 22.22 & 16.28 & 20.75 & 1.829 & 0.383 \\
\hline SE \pm & 62.84 & 21.55 & 18.41 & 20.41 & 1.807 & 0.393 \\
\hline CD & 0.010301025 & 0.174569311 & 0.099398189 & 0.011155467 & 0.00277889 & 0.004899 \\
\hline & 0.03245919 & 0.550079104 & 0.313210074 & 0.035151593 & 0.00875645 & 0.014 \\
\hline
\end{tabular}

\section{References}

1. AOAC Official methods of analysis, 16th Edition, Association of Official Analytical Chemists, Washington, D.C., U.S.A, 1975.

2. Aneja RP, Mathur BN, Chandan RC, Banerjee AK. Heatacid coagulated products in: Technology of Indian Milk Products. Dairy India publication, Delhi, India, 2002, 133-142.

3. De S. Outlines of Dairy Technology. Second Ed. Oxford University Press, New Delhi, 2011.

4. IS: 1224 Part-I. Determination of fat by Garber's method (Revised) Indian Standard Institution, Manak Bhavan, New Delhi, India, 1977.

5. IS: 1479 Part-I. Methods of test for dairy industry: Chemical analysis of milk. Indian Standard Institution, Manak Bhavan, New Delhi, India, 1960.

6. IS: 1479 Part-II. Method of test for dairy industry: Chemical analysis of milk. Indian Standard Institution, Manak Bhavan, New Delhi, India, 1961.

7. Kadam S, Naik P, Sachin M, Dandekar VS, Mayekar AJ. Manufacture of chhana podo by incorporation of mango (Mangifera indica L.) Pulp Cv. Alphonso. Journal of Pharmacognosy and Phytochemistry 2017;6(6):11941196.

8. Sahu JK, Das H. Effect of heating and cooling rates on recovery of milk components during heat-acid coagulation of milk for preparation of Chhana - an Indian soft cottage cheese. International Food Research Journal 2010;17:163-172.

9. Snedecor VG, Cochran GW. Statistical methods, EastWest. Prees pvt. Ltd., New Delhi, 1994. 